\title{
Studies on the Responses of Root, Shoot and Drought Resistance in the Seedlings of Forage Triticale to Water Stress
}

\author{
Wei Zhang, Cheng Li, Chuangjian Qian \& Lianpu Cao (Corresponding author) \\ School of Agriculture, Shihezi University, Shihezi 832003, China \\ E-mail: zhangweivvvvv@163.com
}

\begin{abstract}
In order to investigate the identification index of drought resistance in the forage triticale seedlings, 30 triticales with different genotypes were identified by 20\%-PEG6000. Results showed that responses of each gene to water stress were relatively obvious, water content decreased, the root-shoot ratio enhanced, and leaf curvature and root hyperplasied; There was significant difference among different genotypes, material 27,29,30 showed a good representation to water stress, and their root status were also good. The variation regularity of water content and root hyperplasia was good and they had a great significant correlation. But the variation of root-shoot ratio is relatively complex, other factors should be taken further consideration in the application.
\end{abstract}

Keywords: Water stress, Water content, Root-shoot ratio, Leaf curvature, Root hyperplasia

\section{Introduction}

Drought is a worldwide problem, and only $0.007 \%$ freshwater resources in the world surface could be utilized by human beings. However, the distribution of these limited freshwater is greatly uneven in the world. There are 100 countries or regions which is facing the problem of water deficit, among which 28 countries were listed the topest country under sever deficit (Zhang, 2003). Consequently, studies on the drought resistance of crops are a focus in the agriculture science at present. Triticale is a hybrid of wheat (Triticum) and rye (Secale), and a new cultivar first bred by chromosome engineering breeding technology.Triticale, as a cultivated crops with mass production and economic values first appeared in 1969(Zillinsky, 1974, P. 375). It possesses not only the properties of high production and good quality, but also high resistance to environmental condition of abiotic stress, such as drought and so on. It is abroad suitable to plant in the cropland with bad geological conditions which is not suitable for major economic crops. Investigation of the growth of root and shoot and the variation of water content in triticale under water stress, would not only be important for the screening and identifying excellent drought resistance clones of triticale, but also offer references to the studies on drought resistance of other crops. Therefore, 30 materials with different genotypes were undertaken osmotic stress trial by using 20\%-PEG6000 in the present paper. Water content, root-shoot ratio, leaf curvature and root hyperplasia of the tested materials were observed, and the growth of root and shoot and the variation of water content in triticale under water stress were undertaken comprehensive investigation.

\section{Materials and methods}

\subsection{Experimental materials}

30 advanced lines with different drought resistance bred by wheat crops breeding team of in school of agriculture, Shihezi University were listed in Table 1 in detail, and were cultured in light culture room of Lvzhou ecological laboratory.

\subsection{Material treatment and experiment design}

Plump seeds without diseases were selected, sterilized by $70 \%$ ethanol for $3 \mathrm{~min}$, and washed by deionized water. Seeds were cultured in $10 \mathrm{~cm}$ petri dishes to germinate. Small seedlings were divided into two groups, namely control and stress group until one leaf and a bud, and then transplanted into Hoagland's solution. Seedlings were undertaken water culture with light and ventilation until 3 leaves.

Due to the fast growth rate in triticale seedlings under normal culture, in order to eliminate growth impact on the experiment results, all indices experiment required were determined before stress, and defined as "0h". Then seedlings in stress group were treated by $20 \%-P E G 6000$, and those in control group were still undertaken water culture. Indices were determined after $72 \mathrm{~h}$, and stress and control group were defined as "72hCK" and "72hWS", respectively. Each 
index with three replicates, each replicate with 5 seedlings.

\subsection{Determination content of materials and data processing}

\subsubsection{Determination of water content}

Both aerial and underground part of $72 \mathrm{hCK}$ or $72 \mathrm{hWS}$ seedlings at $0 \mathrm{~h}$ was weighed. Fresh weight (FW) and dry wight (DW) dried until constant weight was determined. Water amounts were obtained by the calculation of the difference between FW and DW. The ratio of water content to FW was material's WC (water content), including leaf and root water content (LWC and RWC). Water loss rate (WL) after stress was calculated using WC, including leaf and root water loss rate (LWL and RWL), and then correlated responses of WC to water stress were investigated.

$$
\begin{gathered}
\mathrm{WC}=[(\mathrm{FW}-\mathrm{DW}) / \mathrm{FW}] \cdot 100 \% \\
\mathrm{WL}=\text { non stressed WC }(1 \text {-stressed } \mathrm{WC})
\end{gathered}
$$

\subsubsection{Determination of root-shoot ratio}

Both aerial and underground parts of $72 \mathrm{hCK}$ or $72 \mathrm{hWS}$ seedlings at $0 \mathrm{~h}$ were weighed. FW and DW dried until constant weight were determined. The ratio of FW or DW of aerial part to underground part was fresh or dry root-shoot ratio, respectively. Correlated responses of root-shoot ratio to water stress were investigated.

Root-shoot ratio(R/T) $=$ Root weight/leaf weight

2.3.3 Determination of leaf curvature under $72 \mathrm{~h}$ stress

For leaves in the seedlings of three leaves were quite tender, according to the results of leave curvature by visual observation, with reference to classification methods of leave curvature introduced by O'Toole et al (1980, PP. 428-432 )and Zhang(1998, PP. 608-612), tested leaves were classified into five curvature grades as follows:

1: flat-unfolded

2: moderately asymmetrical with arcs

3: half-rolled

4: curly

5: curly, like bucket

\subsubsection{Determination of root hyperplasia under $72 \mathrm{~h}$ stress}

Triticale is a plant with quite high drought resistance, and active stress response occurring in the root system of materials was quite obvious under water stress, such as the enlargement of root system, the increment of lateral roots and so on. In our observations, under the stress of high osmotic pressure, it was noted that several materials excluding the enlargement and increment of lateral roots, could result in adventitious roots in the stems during the stress period of $24 \mathrm{~h}$ to $48 \mathrm{~h}$, not similar to those under non stress. Compared to general new roots, adventitious roots possessed the features of wide diameter, long root hair zone and so on. According to the extent of root hyperplasia and the quantity of the observed new roots, root hyperplasia was classified into five grades as follows:

1: no new adventitious roots in basal, no enlargement of root system, no increment of lateral roots, and obvious water loss in root system.

2: no new adventitious roots in basal, no enlargement of root system, and no increment of lateral roots.

3: 0-1 new adventitious roots in basal, visible enlargement of root system and increment of lateral roots.

4: 1-2 new adventitious roots in basal, visible enlargement of root system and increment of lateral roots.

5: more than 2 adventitious roots in basal, visible enlargement of root system and great increment of lateral roots.

\section{Results and analysis}

\subsection{Effects of water stress on LWC and RWC}

In the studies of plants drought resistance, WC was frequently used as a drought resistance index of crops. As seen from Figure 1, without stress treatment, WC difference among different materials was relatively low. Average LWC and RWC in $72 \mathrm{hCK}$ and WC in materials varied insignificantly compared to $0 \mathrm{~h}$. However, both LWC and RWC in $72 \mathrm{hWS}$ treated by $20 \%$ PEG6000 decreased significantly, compared to those under no stress, and WC difference among materials increased significantly. Water loss of leaves was grossly larger than that of roots.

It could be also noted that, during the seedlings of three leaves, under the same treatment, RWC was all higher than LWC, and LWL in most materials was higher than RWL after stress treatment (Table 2), which probably ascribed to the triticale's physiological structure and osmotic pressure in such growth period.

Variance analysis indicated that LWL or RWL in different materials varied significantly (Table 2), namely that 
responses of water condition among different materials to water stress were significantly different. Plant WC after stress treatment was quite higher, material 28, 30 with lower WC had less water loss, while material1, 4 had more water loss.

\subsection{Effects of water stress on root-shoot ratio}

As known from the previous conclusion that during the seedlings of three leaves RWC was all higher than LWC, and LWL in most materials was higher than RWL after stress treatment, fresh root-shoot ratio of triticales in the seedlings was higher than dry root-shoot ratio, and such ratio was susceptible to water variation of plants, which was in agreement with practical results of our experiment. Consequently, from the angle of substance accumulation, for the seek of analysing growth status of root and shoot, fresh root-shoot ratio was more proper.

As seen from Figure 2 and Table 3, after 72h water stress, excluding individual material, root-shoot ration in most materials increased significantly more than that in $72 \mathrm{hCK}$. Compared to $0 \mathrm{~h}$, increment of root-shoot ratio in $72 \mathrm{hWS}$ was less significant than in $72 \mathrm{hCK}$, even reduction in individual material. Compared with $0 \mathrm{~h}$ and $72 \mathrm{hCK}$ without stress treatment, excluding individual material, the later showed a decline trend compared to the former, which conformed to the previous study (Chen, 2004, PP. 574-578). Therefore, we could speculate that significantly more increment of root-shoot ratio in $72 \mathrm{hWS}$ than in $72 \mathrm{hCK}$ didn't necessarily ascribed to the increasing of root system stimulated by stress, but presumably because the growth of triticles was inhibited by water stress compared to the normal water condition.

Variance analysis of different materials' root-shoot ratio under different treatment indicated that difference existed among materials at each treatment, but different treatment failed to induce significantly regular variation of root-shoot ratio differences among materials (Figure2, Table 3). Correlation analysis of root-shoot ratio after stress to WC or WL indicated that there was an insignificantly negative correlation between root-shoot ratio and WC, and an insignificantly positive correlation between root-shoot ratio and WL(Table 6), which was not in line with our prediction. Compared with Table 3 and 2, we could speculate that material with higher root-shoot ratio after stress did not necessarily have a good water condition.

\subsection{Investigation of leaf curvature and its relationship with water after stress}

Several studies have indicated that leaf curvature resulted from the reduction of leaf cell turgor. Leaf curvature used as an index of crops drought resistance have been applied in the breeding and planting (O'Toole, 1980, PP. 428-432; Neil, 1986, PP.257-271). Currently, reports on the leaf curvature of wheat crops in the seedlings were less available, while studies about that in mature period were quite common. Studies on the wheat during flowering stage by Zhang et al(1998, PP. 608-612) indicated that leaf curvature of several materials was large with higher water potential, while leaves of some materials with lower water potential was flat-unfolded.

In the present paper, leave curvature of several materials varied greatly after stress, but leaf curvature of materials with low WC was generally large(Table2, 4). According to the correlation analysis, there was a great significantly negative correlation between leaf curvature and LWC, and a great significantly positive correlation between leaf curvature and WL(Table 6), which was different from the relationship between leaf curvature and drought resistance in mature period. According to the material characteristics in the seedlings of three leaves, due to its tender tissues and high WC, impact of LWC on leave curvature was stronger in the seedlings than in growth or mature period. Accordingly, when leave curvature was applied to investigate the drought resistance of materials, characteristics of growth period should be considered, and materials in the seedlings should be treated differently from those in mature period.

\subsection{Investigation of root hyperplasia and its relationship with water and root-shoot ratio after stress}

Under water stress, there were new adventitious roots among most materials. Their root system got longer, and lateral roots increased. Especially during the stress period from $24 \mathrm{~h}$ to $48 \mathrm{~h}$, new adventitious roots different from new roots under normal water condition appeared the most directly. Compared to the normal new roots, such roots possessed the characteristics of wide diameter, long root hair zone and so on. Taken all previous characteristics together, root hyperplasia of each material was evaluated.

Results showed that materials with root hyperplasia showed good water and growth status after stress (Table2, 5). Correlation analysis indicated that there was a great significantly positive correlation between root hyperplasia and WC, and a great significantly negative correlation between root hyperplasia and WL after stress (Table 6). Therefore, we could speculate that root hyperplasia was of great positive significance to plant's water adsorption.

Correlation analysis indicated that there was an insignificantly negative correlation between root hyperplasia and dry root-shoot ratio after stress (Table 6), which was not in line with the deduction that increment of root-shoot ratio after stress resulted from the stimulation of root system. With reference to the previous results of root-shoot ratio observation, it was noted that increment of root-shoot ratio of several materials didn't ascrib to the increasing of root system, but growth inhibition of the aerial part, even damages to membrane and substance loss induced by strong water stress, which we should pay attention to when we used root-shoot ratio to evaluate drought resistance of materials in the 
seedlings.

\subsection{Cluster analysis of water condition and root hyperplasia among materials under stress}

According to our upper analysis, characteristics of RWC, LWC and root hyperplasia after stress, which were regular and reliable in the experiment, were subjected to UPGMA cluster analysis. First, values of each index should be standardized (Figure 3).

The 30 materials could be grouped into 2 main groups. Group 1 contained 9 materials, i.e. 1, 2, 3, 4, 5, 7, 8, 9, 10. All of them showed a bad water and root condition under water stress; other materials belong to Group 2. All of them showed a good water and root condition under water stress. In group 2, materials with different water and root level could be grouped into several subgroups. Material 27, 29 and 30 showed the best water and root condition, while 1, 4 showed the most sensitivity.

\section{Discussions}

There are many factors affecting the drought resistance of crops, and these factors are not independent, but interact and affect with one another. Therefore, in order to investigate crop drought resistance, attention should not only be paid to identifying representative typical characteristics, but also to their relationship and interaction of those characteristics.

In the present study, results showed that triticale WC varied significantly under stress, and significant difference existed among materials with certain rules, which was easy to investigate and analysis. Meanwhile, active responses of root system to water stress occurred, i.e., lateral roots increased, root system enlarged and new roots grew. The significant correlation between root hyperplasia and WC confirmed that strong mutual impacts existed between water and drought resistance characteristics of root system, positive responses of root system to water stress had a good water condition, and conversely, good water condition in plants could guarantee substance synthesis and promote the growth of root system. All those indicated that possible properties materials with strong drought resistance possessed were of some reference significance for studies on drought resistance of triticales in the seedlings.

Investigations of leaf curvature indicated that there was a significant correlation between leaf curvature and WC, which suggested that curvature variation of tender materials in the seedlings showed a stronger independence to water. Due to the difference from the investigations of leaf curvature in mature period, leaf curvature used as an index for drought resistance, we should fully consider the characteristics of materials in the seedlings.

Investigations of root-shoot ratio indicated that materials with larger or obvious increment of root-shoot ratio didn't show an active impact on their water condition, and results of correlation analysis were not significant. In addition, there was no insignificantly positive correlation between root-shoot ratio and root hyperplasia, which was very different from theory. Consequently, we could speculate that strong water stress could make some materials with less drought resistance growth in aerial part inhibited, damages to membrane, substance loss, and thus root-shoot ratio increased. In view of the complexity of factors affecting root-shoot ratio, when it was applied to identify the drought resistance of triticales, possible factors should be considered, other relative characteristics should be taken into comprehensive consideration and some proper rules should be explored.

Taken together, material 27, 29,30 showed a good water and root condition, while 1,4 showed a bad condition. All these materials should be considered to further application in the following breeding practice about drought resistance.

\section{References}

Chen, X.Y., Gao, Z.H., \& Liu, X.Y., et al. (2004). Effects of water stress on root/shoot relation and grain yield in winter wheat. Acta Agronomica Sinica, 31(5):574-578.

Neil, C., Turner, N.C., \& O’Toole, J.C., et al. (1986). Responses of seven diverse rice cultivars to water deficits. Stress development,canopy temperature, leaf rolling and growth. Field Crops Res, 13:257-271.

O’Toole, J.C., \& Cruz, R.T. (1980). Response of leaf water potential, stomatal resistance, and leaf rolling to water stress. Plant Physiol, 65: 428-432.

Zhang, Z.B. (2003). Foundation on drought-resistance and water-saving physiology. Genetics and breeding of crops. Science press, the first edition.

Zhang, Z.B., \& Shan, L. (1998). Studies on Relationship between drought resistance physiological traits and leaf curl degree and wax of wheat. Acta Agronomica Sinica, 24(5):608-612.

Zillinsky, F.J. (1974). The development of triticale. Adv.Agron, 26:315 
Table 1. Triticale material directory

\begin{tabular}{|c|c|c|c|c|c|}
\hline Serial number & Material & Serial number & Material & Serial number & Material \\
\hline 1 & 04 Spring H147-148 & 11 & 04Spring H159-160 & 21 & 04Spring H431-432 \\
\hline 2 & 04Spring H21-22 & 12 & 04Spring H855-856 & 22 & 04Spring H507-508 \\
\hline 3 & 04Spring H799-800 & 13 & 04Spring H631-632 & 23 & 04Spring H193-194 \\
\hline 4 & 04Spring H513-514 & 14 & 04Spring H127-128 & 24 & 04Spring H567-568 \\
\hline 5 & 04Spring H939-940 & 15 & 04Spring H613-614 & 25 & H04-7 \\
\hline 6 & 04Spring H331-332 & 16 & 04Spring H13-14 & 26 & 04 Spring H499-500 \\
\hline 7 & 04Spring H729-730 & 17 & 04Spring H365-366 & 27 & 04Spring H447-448 \\
\hline 8 & 04Spring H699-700 & 18 & 04Spring H757-758 & 28 & 04 Spring H547-548 \\
\hline 9 & 04Spring H851-852 & 19 & 04Spring H299-300 & 29 & 04 Spring H861-862 \\
\hline 10 & 04Spring H415-416 & 20 & 04Spring H499-500 & 30 & H05-5 \\
\hline
\end{tabular}

Table 2. LWL and RWL of different materials under water stress and variance analysis

\begin{tabular}{|c|c|c|c|c|c|}
\hline $\begin{array}{c}\text { Mat } \\
\text { erial }\end{array}$ & $\begin{array}{c}\text { RWL after stress } \\
\text { compared to } 72 \mathrm{hCK}\end{array}$ & $\begin{array}{c}\text { LWL after stress } \\
\text { compared to } \\
72 \mathrm{hCK}\end{array}$ & $\begin{array}{c}\text { Mat } \\
\text { erial }\end{array}$ & $\begin{array}{c}\text { RWL after stress } \\
\text { compared to } \\
72 \mathrm{hCK}\end{array}$ & $\begin{array}{c}\text { LWL after stress } \\
\text { compared to } 72 \mathrm{hCK}\end{array}$ \\
\hline 1 & $0.119 \pm 0.003 \mathrm{a}$ & $0.162 \pm 0.006 \mathrm{ab}$ & 16 & $0.095 \pm 0.003 \mathrm{ghij}$ & $0.121 \pm 0.010 \mathrm{jjkl}$ \\
\hline 2 & $0.103 \pm 0.002 \mathrm{def}$ & $0.147 \pm 0.003 \mathrm{def}$ & 17 & $0.099 \pm 0.002 \mathrm{fghi}$ & $0.124 \pm 0.006 \mathrm{ijk}$ \\
\hline 3 & $0.104 \pm 0.002 \mathrm{cdef}$ & $0.153 \pm 0.012 \mathrm{bcd}$ & 18 & $0.090 \pm 0.002 \mathrm{jk}$ & $0.129 \pm 0.005 \mathrm{ghij}$ \\
\hline 4 & $0.119 \pm 0.011 \mathrm{a}$ & $0.169 \pm 0.002 \mathrm{a}$ & 19 & $0.092 \pm 0.005 \mathrm{ijk}$ & $0.126 \pm 0.014 \mathrm{hij}$ \\
\hline 5 & $0.107 \pm 0.001 \mathrm{bcde}$ & $0.154 \pm 0.008 \mathrm{bcd}$ & 20 & $0.089 \pm 0.003 \mathrm{jk}$ & $0.127 \pm 0.010 \mathrm{hij}$ \\
\hline 6 & $0.098 \pm 0.005 \mathrm{fghi}$ & $0.155 \pm 0.005 \mathrm{bcd}$ & 21 & $0.090 \pm 0.000 \mathrm{jk}$ & $0.133 \pm 0.008 \mathrm{ghi}$ \\
\hline 7 & $0.105 \pm 0.002 \mathrm{cdef}$ & $0.162 \pm 0.007 \mathrm{ab}$ & 22 & $0.093 \pm 0.003 \mathrm{hijk}$ & $0.113 \pm 0.005 \mathrm{kl}$ \\
\hline 8 & $0.107 \pm 0.004 \mathrm{bcde}$ & $0.152 \pm 0.007 \mathrm{bcd}$ & 23 & $0.100 \pm 0.004 \mathrm{efgh}$ & $0.112 \pm 0.007 \mathrm{kl}$ \\
\hline 9 & $0.111 \pm 0.005 \mathrm{bc}$ & $0.149 \pm 0.008 \mathrm{cde}$ & 24 & $0.086 \pm 0.006 \mathrm{kl}$ & $0.113 \pm 0.003 \mathrm{kl}$ \\
\hline 10 & $0.110 \pm 0.002 \mathrm{bcd}$ & $0.160 \pm 0.008 \mathrm{abc}$ & 25 & $0.086 \pm 0.005 \mathrm{kl}$ & $0.124 \pm 0.004 \mathrm{ijk}$ \\
\hline 11 & $0.101 \pm 0.001 \mathrm{efg}$ & $0.146 \pm 0.007 \mathrm{def}$ & 26 & $0.085 \pm 0.005 \mathrm{kl}$ & $0.117 \pm 0.001 \mathrm{jkl}$ \\
\hline 12 & $0.098 \pm 0.007 \mathrm{fghi}$ & $0.139 \pm 0.005 \mathrm{efg}$ & 27 & $0.082 \pm 0.0061$ & $0.113 \pm 0.001 \mathrm{kl}$ \\
\hline 13 & $0.113 \pm 0.005 \mathrm{ab}$ & $0.155 \pm 0.004 \mathrm{bcd}$ & 28 & $0.080 \pm 0.0121$ & $0.139 \pm 0.012 \mathrm{efg}$ \\
\hline 14 & $0.104 \pm 0.005 \mathrm{cdef}$ & $0.137 \pm 0.007 \mathrm{fgh}$ & 29 & $0.086 \pm 0.003 \mathrm{kl}$ & $0.129 \pm 0.005 \mathrm{ghij}$ \\
\hline 15 & $0.102 \pm 0.002 \mathrm{efg}$ & $0.130 \pm 0.008 \mathrm{ghi}$ & 30 & $0.080 \pm 0.0021$ & $0.110 \pm 0.0071$ \\
\hline
\end{tabular}

Different letters after data in the same column in table showed significant difference at 5\% level. 
Table 3. Data, variance analysis and variation of root-shoot ratio under water stress

\begin{tabular}{|c|c|c|c|c|c|c|c|}
\hline Material & $\begin{array}{l}\text { 0h dry } \\
\text { root-shoot } \\
\text { ratio }\end{array}$ & $\begin{array}{l}72 \mathrm{hCK} \text { dry } \\
\text { root-shoot } \\
\text { ratio }\end{array}$ & $\begin{array}{l}72 \mathrm{~h} \text { dry } \\
\text { root-shoot ratio }\end{array}$ & Material & $\begin{array}{l}\text { 0h dry } \\
\text { root-shoot } \\
\text { ratio }\end{array}$ & $\begin{array}{l}72 \mathrm{hCK} \text { dry } \\
\text { root-shoot } \\
\text { ratio }\end{array}$ & $\begin{array}{l}72 \mathrm{~h} \text { dry root-shoot } \\
\text { ratio }\end{array}$ \\
\hline 1 & $\begin{array}{l}0.259 \pm 0.002 \\
\text { hijk }\end{array}$ & $\begin{array}{l}0.236 \pm 0.021 \\
\text { hijklm }\end{array}$ & $\begin{array}{l}0.323 \pm 0.006 \\
\text { efgh }\end{array}$ & 16 & $\begin{array}{l}0.309 \pm 0.009 \\
\text { defg }\end{array}$ & $\begin{array}{l}0.278 \pm 0.007 \\
\text { cdefgh }\end{array}$ & $0.306 \pm 0.059$ efghi \\
\hline 2 & $\begin{array}{l}0.319 \pm 0.025 \\
\text { def }\end{array}$ & $\begin{array}{l}0.320 \pm 0.029 \\
a b c\end{array}$ & $0.418 \pm 0.019 \mathrm{a}$ & 17 & $\begin{array}{l}0.325 \pm 0.008 \\
\text { de }\end{array}$ & $\begin{array}{l}0.274 \pm 0.004 \\
\text { defghi }\end{array}$ & $0.300 \pm 0.025$ ghi \\
\hline 3 & $\begin{array}{l}0.323 \pm 0.027 \\
\text { def }\end{array}$ & $\begin{array}{l}0.332 \pm 0.027 \\
\mathrm{ab}\end{array}$ & $0.398 \pm 0.018 \mathrm{ab}$ & 18 & $\begin{array}{l}0.261 \pm 0.020 \\
\text { hijk }\end{array}$ & $\begin{array}{l}0.227 \pm 0.015 \\
\mathrm{jklm}\end{array}$ & $0.307 \pm 0.037$ efghi \\
\hline 4 & $\begin{array}{l}0.347 \pm 0.017 \\
\text { bcd }\end{array}$ & $\begin{array}{l}0.332 \pm 0.004 \\
\mathrm{ab}\end{array}$ & $\begin{array}{l}0.372 \pm 0.039 \\
\text { bcd }\end{array}$ & 19 & $\begin{array}{l}0.324 \pm 0.018 \\
\text { de }\end{array}$ & $\begin{array}{l}0.261 \pm 0.034 \\
\text { fghijk }\end{array}$ & $0.336 \pm 0.071$ defg \\
\hline 5 & $\begin{array}{l}0.281 \pm 0.034 \\
\text { efgh }\end{array}$ & $\begin{array}{l}0.227 \pm 0.010 \\
\mathrm{jklm}\end{array}$ & $\begin{array}{l}0.315 \pm 0.049 \\
\text { efgh }\end{array}$ & 20 & $\begin{array}{l}0.235 \pm 0.021 \\
\mathrm{ijkl}\end{array}$ & $\begin{array}{l}0.208 \pm 0.032 \\
\mathrm{mn}\end{array}$ & $0.301 \pm 0.062 \mathrm{ghi}$ \\
\hline 6 & $\begin{array}{l}0.273 \pm 0.007 \\
\text { ghij }\end{array}$ & $\begin{array}{l}0.251 \pm 0.016 \\
\text { fghijklm }\end{array}$ & $\begin{array}{l}0.304 \pm 0.024 \\
\text { fghi }\end{array}$ & 21 & $\begin{array}{l}0.385 \pm 0.018 \\
\mathrm{ab}\end{array}$ & $\begin{array}{l}0.315 \pm 0.026 \\
\text { abcd }\end{array}$ & $0.319 \pm 0.035$ efgh \\
\hline 7 & $\begin{array}{l}0.388 \pm 0.010 \\
\mathrm{ab}\end{array}$ & $\begin{array}{l}0.348 \pm 0.007 \\
\text { a }\end{array}$ & $\begin{array}{l}0.376 \pm 0.052 \\
\text { abcd }\end{array}$ & 22 & $\begin{array}{l}0.279 \pm 0.034 \\
\text { fghi }\end{array}$ & $\begin{array}{l}0.247 \pm 0.023 \\
\text { ghijklm }\end{array}$ & $0.370 \pm 0.013 \mathrm{bcd}$ \\
\hline 8 & $\begin{array}{l}0.284 \pm 0.014 \\
\text { efgh }\end{array}$ & $\begin{array}{l}0.260 \pm 0.004 \\
\text { fghijk }\end{array}$ & $0.301 \pm 0.026 \mathrm{ghi}$ & 23 & $\begin{array}{l}0.286 \pm 0.008 \\
\text { efgh }\end{array}$ & $\begin{array}{l}0.220 \pm 0.008 \\
\mathrm{klm}\end{array}$ & $0.346 \pm 0.019$ cdef \\
\hline 9 & $\begin{array}{l}0.219 \pm 0.008 \\
\mathrm{k} 1\end{array}$ & $\begin{array}{l}0.173 \pm 0.017 \\
\mathrm{n}\end{array}$ & $0.265 \pm 0.054 \mathrm{ij}$ & 24 & $\begin{array}{l}0.268 \pm 0.011 \\
\text { ghij }\end{array}$ & $\begin{array}{l}0.255 \pm 0.020 \\
\text { fghijkl }\end{array}$ & $0.378 \pm 0.015 \mathrm{abcd}$ \\
\hline 10 & $\begin{array}{l}0.311 \pm 0.030 \\
\operatorname{defg}\end{array}$ & $\begin{array}{l}0.235 \pm 0.009 \\
\text { hijklm }\end{array}$ & $\begin{array}{l}0.349 \pm 0.041 \\
\text { cde }\end{array}$ & 25 & $\begin{array}{l}0.229 \pm 0.016 \\
\mathrm{jkl}\end{array}$ & $\begin{array}{l}0.232 \pm 0.009 \\
\text { ijklm }\end{array}$ & $0.282 \pm 0.021 \mathrm{hi}$ \\
\hline 11 & $\begin{array}{l}0.376 \pm 0.031 \\
a b c\end{array}$ & $\begin{array}{l}0.306 \pm 0.025 \\
\text { abcde }\end{array}$ & $0.414 \pm 0.060 \mathrm{ab}$ & 26 & $\begin{array}{l}0.281 \pm 0.043 \\
\text { efgh }\end{array}$ & $\begin{array}{l}0.266 \pm 0.035 \\
\text { efghij }\end{array}$ & $0.322 \pm 0.024$ efgh \\
\hline 12 & $\begin{array}{l}0.332 \pm 0.020 \\
\mathrm{~cd}\end{array}$ & $\begin{array}{l}0.255 \pm 0.010 \\
\text { fghijkl }\end{array}$ & $\begin{array}{l}0.348 \pm 0.011 \\
\text { cdef }\end{array}$ & 27 & $\begin{array}{l}0.372 \pm 0.011 \\
\mathrm{abc}\end{array}$ & $\begin{array}{l}0.350 \pm 0.020 \\
\text { a }\end{array}$ & $0.321 \pm 0.021$ efgh \\
\hline 13 & $\begin{array}{l}0.313 \pm 0.038 \\
\text { defg }\end{array}$ & $\begin{array}{l}0.252 \pm 0.012 \\
\text { fghijklm }\end{array}$ & $\begin{array}{l}0.334 \pm 0.046 \\
\text { defg }\end{array}$ & 28 & $0.214 \pm 0.0151$ & $\begin{array}{l}0.211 \pm 0.031 \\
\operatorname{lmn}\end{array}$ & $0.295 \pm 0.027 \mathrm{ghi}$ \\
\hline 14 & $0.397 \pm 0.015 \mathrm{a}$ & $\begin{array}{l}0.294 \pm 0.026 \\
\text { bcdef }\end{array}$ & $\begin{array}{l}0.390 \pm 0.019 \\
\mathrm{abc}\end{array}$ & 29 & $0.213 \pm 0.0351$ & $\begin{array}{l}0.225 \pm 0.024 \\
\mathrm{jklm}\end{array}$ & $0.221 \pm 0.011 \mathrm{j}$ \\
\hline 15 & $\begin{array}{l}0.353 \pm 0.036 \\
\text { abcd }\end{array}$ & $\begin{array}{l}0.286 \pm 0.028 \\
\text { cdefg }\end{array}$ & $\begin{array}{l}0.390 \pm 0.011 \\
\mathrm{abc}\end{array}$ & 30 & $\begin{array}{l}0.254 \pm 0.019 \\
\text { hijkl }\end{array}$ & $\begin{array}{l}0.281 \pm 0.037 \\
\text { cdefg }\end{array}$ & $0.319 \pm 0.043$ efgh \\
\hline
\end{tabular}

Different letters after data in the same column in table showed significant difference at $5 \%$ level. 
Table 4. Leaf curvature of 30 materials under water stress

\begin{tabular}{|l|r|r|r|r|r|r|r|r|r|r|r|r|r|r|r|}
\hline Material & 1 & 2 & 3 & 4 & 5 & 6 & 7 & 8 & 9 & 10 & 11 & 12 & 13 & 14 & 15 \\
\hline Grade of leave curvature & 5 & 5 & 5 & 5 & 4 & 5 & 5 & 3 & 4 & 5 & 5 & 4 & 4 & 3 & 3 \\
\hline Material & 16 & 17 & 18 & 19 & 20 & 21 & 22 & 23 & 24 & 25 & 26 & 27 & 28 & 29 & 30 \\
\hline & & & & & & & & & & & & & & & \\
Grade of leave curvature & 3 & 3 & 1 & 3 & 3 & 5 & 5 & 4 & 3 & 2 & 1 & 3 & 3 & 1 & 1 \\
\hline
\end{tabular}

Table 5. Root hyperplasia of 30 materials under water stress

\begin{tabular}{|l|r|r|r|r|r|r|r|r|r|r|r|r|r|r|r|}
\hline Material & 1 & 2 & 3 & 4 & 5 & 6 & 7 & 8 & 9 & 10 & 11 & 12 & 13 & 14 & 15 \\
\hline Grade of root hyperplasia & 2 & 2 & 2 & 2 & 2 & 2 & 2 & 2 & 2 & 2 & 4 & 2 & 4 & 4 & 4 \\
\hline Material & 16 & 17 & 18 & 19 & 20 & 21 & 22 & 23 & 24 & 25 & 26 & 27 & 28 & 29 & 30 \\
\hline Grade of root hyperplasia & 4 & 2 & 3 & 2 & 3 & 2 & 3 & 2 & 3 & 4 & 4 & 5 & 4 & 5 & 5 \\
\hline
\end{tabular}

Table 6. Correlation among different characteristics under water stress

\begin{tabular}{|c|c|c|c|c|c|c|c|}
\hline & $\begin{array}{l}\text { 72hWS } \\
\text { RWC }\end{array}$ & $\begin{array}{l}\text { 72hWS } \\
\text { LWC }\end{array}$ & $\begin{array}{l}\text { 72hWS } \\
\text { RWL }\end{array}$ & $\begin{array}{l}\text { 72hWS } \\
\text { LWL }\end{array}$ & $\begin{array}{l}\text { 72hWS Dry } \\
\text { root-shoot ratio }\end{array}$ & $\begin{array}{c}\text { 72hWS Leaf } \\
\text { curvature }\end{array}$ & $\begin{array}{l}\text { 72h Root } \\
\text { hyperplasia }\end{array}$ \\
\hline 72hWS RWC & 1 & & & & & & \\
\hline 72hWS LWC & $0.802^{* *}$ & 1 & & & & & \\
\hline 72hWS RWL & $-0.998^{* *}$ & $-0.792^{* *}$ & 1 & & & & \\
\hline 72hWS LWL & $-0.805^{* *}$ & $-0.997^{* *}$ & $0.795^{* *}$ & 1 & & & \\
\hline $\begin{array}{c}\text { 72hWS Dry root-shoot } \\
\text { ratio }\end{array}$ & -0.324 & -0.173 & 0.316 & 0.176 & 1 & & \\
\hline 72hWS Leaf curvature & $-0.637^{* *}$ & $-0.607^{* *}$ & $0.644^{* *}$ & $0.616^{* *}$ & $0.521^{* *}$ & 1 & \\
\hline $\begin{array}{l}\text { 72hWS Root } \\
\text { hyperplasia }\end{array}$ & $0.575^{* *}$ & $0.495^{* *}$ & $-0.575^{* *}$ & $-0.511^{* *}$ & -0.195 & $-0.635^{* *}$ & 1 \\
\hline
\end{tabular}

“*” and "***" indicated significant correlation at 5\% and $1 \%$ level, respectively.

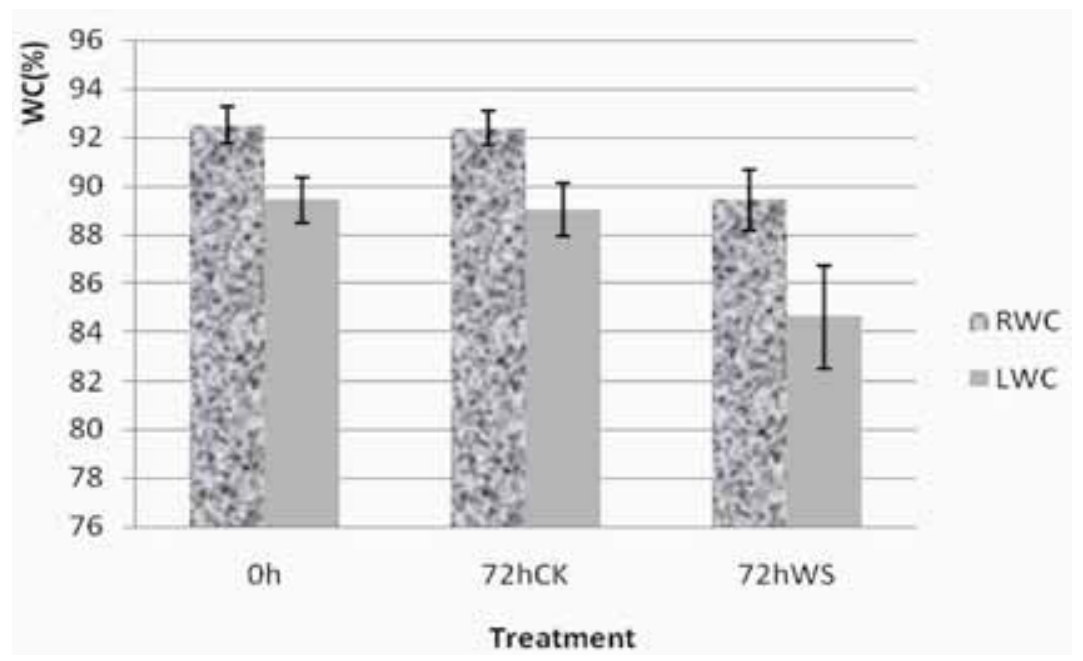

Figure 1. Effects of water stress on RWC and LWC in triticales 


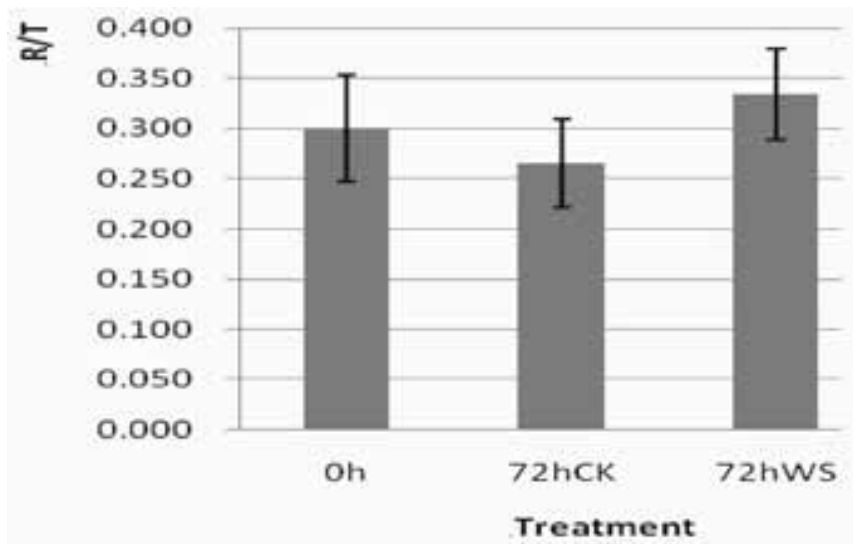

Figure 2. Effects of water stress on root-shoot ratio in triticales

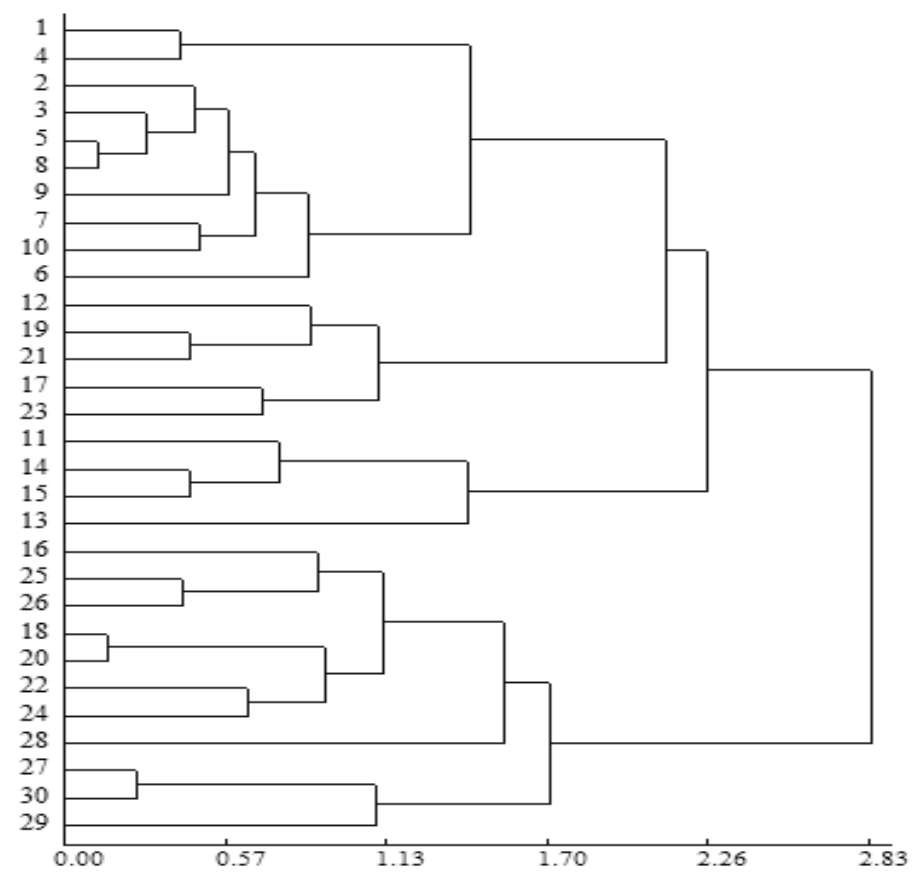

Figure 3. The phylogenetic dendrogram of WC and root hyperplasia of 30 materials using UPGMA cluster analysis 